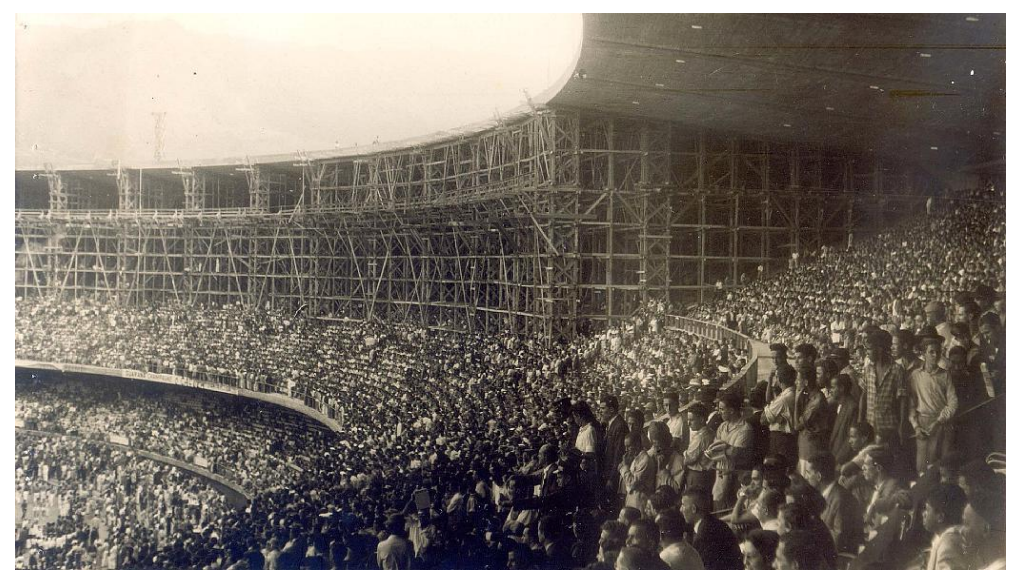

\title{
Maracanã como mídia urbana: as narrativas jornalísticas, apropriações e interações no torcer no "maior do mundo"
}

Maracanã as urban media: journalistic narratives, appropriations and interactions in the support on the "biggest in the world".

\section{Francisco Angelo Brinati ${ }^{1}$}

Filipe Mostaro $^{2}$

\begin{abstract}
Resumo:
A narrativa da construção do Maracanã para a Copa de 1950 foi recheada de disputas simbólicas e de tentativas de se impor novas representações para este espaço urbano. Neste artigo investigamos as narrativas presentes nos jornais $O$ Globo, A Noite, Diário da Noite e Jornal dos Sports atentando para duas questões. A primeira é como a edificação do estádio se tornou um pilar essencial na elaboração discursiva da entrada do país na Modernidade. A segunda é indicar como o espaço urbano do estádio suscitou negociações simbólicas sobre o torcer e ocupar esta construção. Nossa argumentação é que o Maracanã se torna uma mídia urbana, palco para disputas das práticas existentes na cidade que comumente extrapolam o viés esportivo, englobando narrativas políticas, econômicas e sociais.
\end{abstract}

Palavras-chave: Maracanã; narrativas, mídia urbana, Copa de 1950

\begin{abstract}
:
The narrative of the Maracanã's construction for the 1950's World Cup was stuffed with symbolic disputes ans attempts to impose news representations for this urban space. In this paper we investigate the narratives in the newspaper O Globo, A Noite, Diario da Noite and Jornal dos Sports considering two issues. First, is how the bulding of the stadium became and essential Pillar in the discursive elaboration of country's entry into Modernity. The second is to indicate how the urban space of the stadium has aroused symbolic negotiations about "the cheer" and occupying this construction. Our contention is that Maracanã becomes an urban media, local for disputes of the existing practices in the city that generally extrapolate the Sport narratives, ecompassing political, economic and social narratives.
\end{abstract}

Keywords: Maracanã, narratives, urban media, World Cup 1950

\footnotetext{
${ }^{1}$ Doutor em Comunicação pela Uerj (Universidade do Estado do Rio de Janeiro), e Professor Adjunto da Faculdade de Comunicação Social da UFSJ (Universidade Federal de São João Del Rey. Email: chicobrinati@yahoo.com.br. ORCID: https://orcid.org/0000-0002-3793-3539

${ }^{2}$ Doutorando pelo PPGCOM da Uerj (Universidade do Estado do Rio de Janeiro) e Professor Substituto da Faculdade de Comunicação Social da Uerj. Email: filipemostaro@hotmail.com. ORCID: https:// orcid.org/0000-00016600-5953
} 


\section{Introdução}

O estádio jornalista Mario Filho, popularmente conhecido como Maracanã, articula uma série de significados que vão desde a metonímia da grandeza do futebol na cultura nacional, com a expressão "maior do mundo" como seu principal pilar, até o local de embates públicos entre torcidas e suas contendas. O presente artigo investiga dois pontos que julgamos determinantes neste processo. $\mathrm{O}$ primeiro é demonstrar a concepção da construção do estádio como um elemento crucial da narrativa da entrada do país na Modernidade e de sustentação do orgulho nacional. Nesta obra, tida como monumental, um novo espaço público se articula como lócus de produção de significados e se apresenta, não só à sociedade carioca, mas também à sociedade brasileira, por conta das narrativas da Capital Federal irradiarem para todo o país. O segundo ponto é refletir sobre como esse "palco esportivo" exerce um papel decisivo na esfera pública (Habermas, 1984) no campo futebolístico e em alguns momentos extrapola tal viés estritamente esportivo. Partimos da ideia que o Maracanã e suas narrativas formulam hábitos de torcer, indicando comportamentos, que, neste jogo de apropriações constantes feitas pelos torcedores, demonstram como as sensações e os hiperestímulos acionados pelo esporte reconfiguram os sentidos de práticas culturais, políticas e simbólicas.

Para desenvolver essas argumentações, na primeira parte do trabalho vamos indicar como a articulação de vários elementos propiciou ao futebol penetrar de maneira robusta no imaginário nacional e suscitou a construção de um estádio da magnitude do Maracanã. Nossa intenção é indicar os vestígios e traços comunicacionais presentes nos jornais como pistas das representações engendradas sobre o estádio. Os periódicos foram escolhidos por pertenceram a grupos de comunicação que mantinham rádios com extensiva cobertura esportiva. A ideia é que esses jornais seguiam a linha editorial das rádios e reverberavam tais ideologias, atingindo os três níveis de público proposto por Marialva Barbosa (2012). Deste modo, investigaremos como as narrativas dos jornais $O$ Globo (Rádio Globo), A Noite (Rádio Nacional), Diário da Noite (Rádio Tupi) e Jornal dos Sports (este último pela presença de Mario Filho, considerado maior entusiasta da construção) estimularam a ideia do estádio como o grande símbolo tanto do futebol nacional, como da Modernidade brasileira.

A Análise de Narrativas jornalísticas que seguiremos neste trabalho se baseia nas ideias de Paul Ricouer (2010) e Luiz Gonzaga Motta (2007). Entendemos a narrativa 
como um processo que envolve elementos além do texto e sua materialidade (GUMBRECHT, 2013). A narrativa engloba o contexto, a atmosfera, que se influenciam mutuamente. Em suma, o processo narrativo é uma relação de coconstrução de sentidos entre os interlocutores da interação, como defende Motta (2013). Neste sentido o conceito de intriga de Ricouer será utilizado para analisarmos a narrativa midiática. A intriga pode ser entendida como a escolha de ações humanas que vão tornar a narrativa compreensível, com início, meio e fim e que lhe darão determinado sentido de acordo com o que é contado e aquilo que não é contado, através de escolhas e angulações. A narrativa jornalística procura apagar marcas de subjetividade e interpretação do jornalista na construção da intriga, como se o fato falasse por si só, criando o "efeito de real", colocando a notícia e seu relato como uma voz narrativa recheada de poder simbólico definindo a "realidade" da situação social (MOTTA, 2013). São esses recursos que investigaremos atentando para a seleção de argumentos e acontecimentos trazidos pelos jornais que almejavam moldar a significação do Maracanã.

Em seguida voltaremos nosso olhar para a formação de hábitos que "ensinavam a torcer" neste novo cenário urbano esportivo. Nesta interação entre o que era pretendido pela narrativa e o que foi ressignificado pelos torcedores, refletiremos sobre as formas de se comportar e interagir com base nos ritos simbólicos presentes no estádio que as reportagens dos periódicos analisados indicavam.

\section{O Futebol como elemento da Modernidade}

O futebol se tornou ao longo do tempo um dos elementos centrais da construção de uma identidade nacional. Suas primeiras apropriações pretendidas pela elite brasileira foram recebendo novos sentidos com a sua distribuição pelo país através dos portos e fábricas inglesas (MASCARENHAS, 2014). O que seria um esporte amador e praticado por uma camada da população que buscava reproduzir hábitos nobres ingleses, teve na sua popularização e na prática das camadas menos abastadas uma reapropriação de sentidos. Grosso modo, o que era para ser elitista, logo virou algo popular. No início da década de 1910, clubes que nasceram para se dedicar as regatas, como Vasco, Flamengo e Botafogo, criaram seus departamentos de futebol e de outras modalidades indicando como o esporte se entranhava na sociedade. Essa articulação foi proporcionando, em especial ao futebol, um apelo popular importante na construção de 
uma nova cidade, repleta de contrastes, que almejava uma modernidade seguindo os padrões europeus e via nos valores do esporte moderno, maneiras de organizar, controlar, impor regras e civilizar a sociedade, conforme Norbert Elias (1993) destacou$^{3}$. A disputa do Sul-Americano de 1919 estabeleceu um marco nesta "linha evolutiva" do esporte no país e instaurou o futebol como algo popular como Sevcenko (1994) e Sarmento (2013) destacam.

Todavia, neste jogo de apropriações e controle sobre o esporte, alguns pontos como a questão racial e o amadorismo indicavam opiniões contrastantes. As décadas de 1920 e 1930 foram o auge destas disputas com a criação de ligas amadoras e profissionais. Tais debates encontrariam, apenas com a chegada do presidente Getúlio Vargas ao poder, uma narrativa mais próxima da conciliação. Getúlio acreditava no poder mobilizador do futebol e, consequentemente, em sua relevância como elemento na construção de um pensamento nacional que aglutinasse diferentes opiniões e segmentos. Assim, passou a moldar a representação deste esporte como nosso pilar cultural. A narrativa do governo passa então a sugerir a interação do futebol com outros campos, que também passavam por reformulações na conjuntura nacional, postulando como necessário, por exemplo, profissionalizar o esporte e encampá-lo nos ideais trabalhistas do Estado Novo, com o argumento de que as leis do trabalho seriam leis que manteriam a harmonia social. Apropriar-se das narrativas sobre o futebol se torna ponto-chave para o governo Vargas. Consequentemente, não tardou para que narrativas sobre o caráter democrático deste esporte sugerissem uma alternativa de ascensão social dos negros na sociedade através do futebol ${ }^{4}$. Ao receberem salários considerados altos e conquistarem um destaque social importante como ídolos nacionais, jogadores negros como Leônidas e Domingos da Guia tiveram suas trajetórias narradas como a cristalização do futebol em potencializar oportunidades no contexto da modernidade que o Brasil adentrava. Destacamos aqui que esta visão procurava amenizar as divisões sociais através do esporte, como uma maneira de aglutinar o país em torno de algo popular e de fácil compreensão, como o futebol. Isso não enterra as visões racistas,

\footnotetext{
${ }^{3}$ Essa negociação de sentidos sobre o esporte no país foi repleta de disputas e posições antagônicas. Toledo (2000) relata que uma parcela da população, representada pelo médico carioca Sussenkind de Mendonça e o escritor Lima Barreto, era contra a prática de tais atividades esportivas, criando, inclusive, uma liga contra o futebol nos anos 1920. Para este grupo, assistir a um jogo era algo mais inútil do que efetivamente jogá-lo.

${ }^{4}$ Leite Lopes (1994) destaca que o jornalista Mario Filho defendia o profissionalismo como meio de emancipação dos negros na sociedade. No nosso entendimento, tal posição foi evidenciada em suas colunas, alavancando o debate em torno do tema.
} 
ainda presentes na sociedade. A narrativa do futebol como ferramenta de integração nacional selecionava o que no momento era conveniente e que, de forma eficiente, através da articulação entre o campo político (era necessária manter a unidade nacional), econômico (o futebol surgia com um mercado de consumo promissor) e social (que almejava os direitos civis, entre eles o trabalhista), sedimentou uma visão romântica e harmônica de brasilidade, excluindo pensamentos antagônicos, ou indicando-os como “em equilíbrio". A ideia de "democracia social” de Gilberto Freyre (1933) evidenciada em seu livro Casa Grande e Senzala se encaixa nesta articulação. Acreditamos que por ir de encontro a uma narrativa que se coadunava aos interesses da época, a premissa de Freyre foi adotada como a proposição correta para solidificar o peso do futebol na formação identitária nacional naquele período.

Para nós, o Estado Novo e a Copa de 1938 contribuíram para alicerçar a lógica da democracia no futebol e integração nacional simbolizadas pelo esporte, em especial pela seleção brasileira. Freyre defendeu em no artigo Football Mulato publicado no dia 17 de junho de 1938 no jornal Diário de Pernambuco, durante a competição, que pela primeira vez o Brasil levava a Copa um time "francamente" nacional com a presença de negros, brancos e índios, cristalizando a imagem da mestiçagem como um atributo positivo da nação, já que creditou nosso sucesso no torneio (terceiro lugar) a esta presença de diferentes etnias, algo que outras nações supostamente não tinham. $\mathrm{O}$ futebol "apagaria" nossas diferenças, erguendo uma homogeneidade da nação em torno da mestiçagem. A linguagem radiofônica se encarregou de levar esta ideia para todo o país, enquanto os jornais impressos tratavam de reforçar os argumentos na esfera pública letrada. Seria o que Marialva Barbosa (2012) destaca como o público leitor, que analisa a informação, o ouvinte que absorve e aqueles que participavam dos debates reproduzindo o que ouviu dizer. Criou-se então uma esfera pública ampla e que contribuiu para enraizar tais princípios na sociedade brasileira.

Aqui é fundamental ressaltarmos a parceria mídia e esporte no sentido de representar essa passagem para o mundo moderno e inserir novos tipos de estímulos na sociedade. Nesta pedagogia de como se portar e se habituar à Modernidade, a oralidade do rádio, o letramento dos jornais e a intensidade das paixões que o esporte provocava se tornam elementos decisivos no contexto no qual se pretende implantar a concepção do que seria moderno. Logicamente que na construção de espaços urbanos, esses dois elementos (mídia e esporte) não seriam desprezados na esfera pública. Acreditamos que 
tal processo foi possível através da formulação (também intensificada na concepção de modernidade) de uma prática social onde o jornalista e o locutor de rádio seriam pessoas legitimadas para falar na esfera pública, persuadindo o seu público, com o apoio da noção do esporte como prática inerente a modernidade e como algo que mexe com o pathos.

Hobsbawn (2015) chama a atenção para este movimento com o surgimento das políticas de massas no final do século XIX e o papel de tais narrativas de origem dos Estados-nação operando no sentido de manutenção da ordem social. Seriam tradições inventadas para ordenar hábitos e práticas sociais. A “invenção de tradições" (HOBSBAWN, 2012) sobre a brasilidade e o futebol podem ser analisadas nesta concepção. Da Matta (1979), por exemplo, compreende este esporte como o local onde a nação pode se organizar coletivamente, ter sua identidade formulada por esferas que não segregaria segmentos sociais de participação e ativa intervenção. $O$ futebol seria, com suas regras claras e igualdade de condições, um local onde subterfúgios como o nome e classe social para levar vantagem não teriam valor, apenas o talento, o "dom" nato do atleta seria o motivo de seu sucesso. Essa dramatização do futebol o propõe como espaço que ocultaria uma luta de classes explícita, em uma associação que levantaria a hipótese de que, no imaginário do torcedor, o mais pobre poderia vencer o mais rico. Para Da Matta, essa simbologia, que não abalaria de maneira efetiva as estruturas sociais, foi sustentada na narrativa criada sobre o país, agradando as elites. Aqui, sugerimos que o aspecto democrático, pretendido pela narrativa política, mesmo em um governo ditatorial, encontra na ideia de Modernidade, de controle social e de igualdade de oportunidades (sentidos que o futebol poderia acionar), a fortificação da concepção de um novo país, nos moldes europeus, exaltados como "corretos" e "civilizatórios".

Com essa articulação de fatores, tais narrativas foram adentrando o imaginário social brasileiro, robustecendo a visão do futebol como exemplo da modernidade que o país desejava. A própria "febre esportiva", baseada na ideia de ativismo, de colocar o corpo em movimento com inspirações em doutrinas militares, destacada por Novais e Sevcenko (1998), tornam-se orientações para a construção de novos hábitos, focados na aura de "algo moderno". Praticar e assistir o esporte de maneira vigorosa surgia como algo espontâneo e inevitável na Modernidade, como um pulso elétrico que percorria o corpo e implacavelmente seduzia o indivíduo à atividade física e as sensações que o jogo proporcionaria. Formam-se nestes períodos um número considerável de 
associações esportivas, além da educação física obrigatória nas escolas (NOVAIS e SEVCENKO, 1998). No cenário da moda, surgem roupas com inspiração esportiva, mais adaptadas ao movimento do corpo e a expô-lo, já que o sentido social de um corpo musculoso não mais remetia-se exclusivamente aos trabalhadores braçais, ressignificando-o como um exemplo de higiene corporal, sugerida pelos ideais sanitaristas, outra característica da modernidade ${ }^{5}$. Esta articulação pode ser simbolizada pelo clichê "esporte é saúde", onde o corpo atlético, tanto do praticante quanto do atleta profissional se torna um ícone da ideologia da Modernidade, como nas narrativas do filme Olympia de Leni Riefenstahl, por exemplo, que exaltam a beleza do corpo alemão, pronto para o esporte e para a guerra ${ }^{6}$.

Assim, essa pulsação inevitável pelos movimentos esportivos insere ingredientes decisivos no imaginário sobre o futebol, criando o clichê amplamente usado para definilo como "paixão nacional". Concomitantemente, cria-se uma demanda por praças esportivas que abarquem cada vez mais pessoas, fazendo com que os estádios de futebol surgissem como espaços urbanos importantes e de grandes concentrações das chamadas massas $^{7}$. As capacidades que antes se limitavam a dez mil pessoas, foram aumentando, demonstrando o crescimento pelo interesse de não só acompanhar as notícias e informações pelo rádio e jornal, mas sim em viver as emoções de estar na multidão "vendo ao vivo" as partidas de futebol ${ }^{8}$. Este bombardeio de estímulos oferecidos pela cidade moderna demarcava o ritmo de vida mais acelerado e de movimentação nas cidades, estimulando tais aglomerações (SINGER, 2004). A aceleração instigava a busca pelas informações "instantâneas" dos acontecimentos, acentuando os meios de comunicações como fabricadores de um tempo presente cada vez mais intenso (FRANCISCATO, 2005). Esta intensidade também amplificava as emoções e choques sensoriais. Neste sentido, acreditamos que o estádio articula esses elementos como o local das emoções apresentadas pela Modernidade.

\footnotetext{
${ }^{5}$ Para melhor entendimento deste processo e suas significações na sociedade carioca ao longo da primeira metade do século XX, destacamos o trabalho de Julia O’Donnell, A Invenção de Copacabana (2013).

${ }^{6}$ Neste sentido indicamos o artigo Jogos Olímpicos de Berlim 1936: O uso do esporte para fins nada esportivos, MOSTARO (2012).

7 Toledo (2000) enfatiza que a partir dos anos 1940 e 1950, com a ajuda dos jornais e do rádio, foi demarcada uma maior aceitação dos torcedores, dentro do espírito do esporte como algo coletivo, induzindo a formação das primeiras torcidas organizadas. Antes, ainda segundo Toledo, o público dos estádios era tratado como "assistência", inferindo um caráter passivo.

${ }^{8}$ O Estádio do Pacaembu foi inaugurado em São Paulo neste período com uma capacidade para 50 mil pessoas.
} 


\section{Para "nossa maior paixão", o "colosso do Derby"}

A procura por acompanhar nossa "maior paixão nacional" cresceu de tal forma nos anos 1940 que o estádio de São Januário, pertencente ao Vasco, com capacidade para 35 mil pessoas passou a se tornar "pequeno" para tais emoções. No mesmo período, a oportunidade de sediar o evento como a Copa do Mundo surgiu nas narrativas como a chance de mostrar ao mundo que, enfim, o Brasil havia adentrado a Modernidade. Dentre as principais condições para indicar essa posição do país perante o mundo a construção do maior estádio do planeta foi seu sustentáculo essencial. Todavia, a edificação do principal estádio da Copa foi regada de intensos debates. O locutor de rádio e vereador Ary Barroso e o jornalista Mário Filho negavam a reforma de São Januário, entendendo que tal realização, ao invés de erguer um novo estádio, seria um improviso que indicaria uma incapacidade da nação. Assim, comandaram a campanha para a construção do estádio na região do antigo Derby Club, próximo ao bairro de Vila Isabel e do Maracanã. A edificação em tal região facilitaria o acesso tanto dos moradores da Zona Norte, como os da Zona Sul carioca. Carlos Lacerda, então vereador, depois de relutar sobre a construção de um estádio, cedeu em sua posição, mas passou a querê-lo em Jacarepaguá e com uma capacidade menor, já que afirmava não haver público para encher o Maracanã. Segundo ele o Brasil não teria cimento suficiente para tal obra. Conforme bem colocou Hilário Franco Júnior, tais discussões: "correspondiam ao clima acalorado da democracia populista, que debatia de forma maniqueísta" (FRANCO JR., 2007, p.88). Sinalizamos que o contexto de redemocratização estimulava essa formação de debates através de jornais e rádios, produzindo opiniões e destacando figuras públicas como as citadas acima no que Habermas (1984) entende como "árbitro das artes", pessoas que definiriam o que seria bom, em uma forma de pedagogia do público, vestidas de uma autoridade de especialistas no assunto, legitimando discursos em meio a uma profusão de opiniões.

Para Mario Filho e Ary Barroso, por exemplo, apenas uma obra monumental como a do Maracanã conseguiria demonstrar a força do futebol em nossa sociedade. Destacamos aqui que a magnitude das obras para um grande evento sintetiza a imagem que o país deseja apresentar ao mundo. Quanto mais grandioso, maior o orgulho patriótico e a "publicidade gratuita" do país no exterior. Mario Filho passou a usar sua coluna no Jornal dos Sports e n'O Globo para defender suas ideias e Ary Barroso fez o 
mesmo em seus programas de rádio. Em 13 de maio de 1947, Mario Filho entendia que a construção de um estádio de grande porte mostraria união nacional e a "capacidade do Brasil se organizar e promover um certame desta natureza, privilégio que todas as nações disputam como uma oportunidade de oferecer ao mundo uma visão de seu desenvolvimento" (O GLOBO, 13/05/1947, p.10). Esta "necessidade" se tornou um assunto recorrente no Jornal dos Sports e n'O Globo, com influência de Mario Filho, deixando evidente o papel dos meios de comunicação na mobilização da opinião pública sobre a Copa, que aconteceria dentro de três anos. Esse discurso também funcionava como pressão sobre o governo para ceder às propostas do grupo político de Mario Filho. A reportagem do dia 17 de maio de 1947, por exemplo, afirma que o governo via com descaso a construção de um estádio e que "não compreendia a grandeza da iniciativa" (JORNAL DOS SPORTS, 17/05/1950, p.10), em uma nítida intenção de induzir uma ação das autoridades através da condução das opiniões estabelecidas como racionais e corretas na esfera pública.

Já em 1950, após a inauguração do estádio municipal, um retrospecto do jornal O Globo deixa claro esta posição neste agendamento do debate:

Debates acalorados na Câmara dos vereadores marcaram o início da campanha. $\mathrm{O}$ povo não discutia. $\mathrm{O}$ povo tinha apenas um desejo: que fosse construído o estádio e num lugar acessível. Quando o general Mendes de Moraes ordenou o início da construção, O Globo e Jornal dos Sports prestigiaram, de todas maneiras, o empreendimento $(\mathrm{O}$ GLOBO, 20/06/1950, p.3).

A narrativa procura imprimir a ideia de que a opinião conduzida pelo jornal era o desejo da população. O jornal escolhe a expressão "colosso do Derby" para nomear o estádio.

Acreditamos que ao se clamar pelo novo estádio como algo gigantesco consolida-se a importância do esporte na sociedade, como o jornal $O$ Globo defende, entendendo-o como "a concretização de um sonho de todas as épocas: a de um estádio à altura da grandeza e do prestígio do football brasileiro" (O GLOBO, 17/06/1950, p.6). Além disso, a obra insere-se na concepção de desenvolvimento nacional, fazendo o Brasil entrar para o "time das grandes nações". Acreditamos que o "gigante de concreto" com capacidade para mais de 180 mil pessoas, cravado no coração geográfico da cidade reflete a ideia de urbanização e melhorias das áreas adjacentes (presentes em algumas reportagens), alargando o conceito de centro da cidade, tornando-se também, como o jornal A Noite define, "outro motivo de atração turística" (A NOITE, 
15/06/1950, p.10). Deste modo, remodelou-se o espaço urbano, principalmente no entorno do "Colosso do Derby", tornando o estádio uma marca da cidade. Sua localização, entre a Zona Sul e o início da Zona Norte, criou novas fronteiras de circulação dentro da metrópole brasileira moderna, tornando locais antes frequentados por um determinado grupo de pessoas, mais diversificadamente coabitados. O discurso de que classes sociais diferentes estavam juntas por um mesmo ideal ao torcer pela seleção no estádio também aparece nos jornais. O sentido de espaço democrático na narrativa é nítido.

O jornal A Noite também ressaltava que a obra havia sido feita inteiramente por “firmas e operários brasileiros" (15/06/1950, p.10), em menos de dois anos, mostrando que o país não dependia mais de tecnologia, dinheiro e mão de obra externa para executar seus projetos, indicando uma verve ufanista nos preparativos para a competição. Percebe-se um diálogo estreito entre a elevação da autoestima nacional e a propaganda do nosso país para o mundo, enfatizando-se o tom patriótico dos jornais ao louvar de forma incisiva a construção do estádio. Outro trecho do jornal A Noite, este no dia da inauguração do Maracanã, corrobora com a ideia aqui exposta:

O Estádio Municipal é um gigante de cimento armado, construído para admiração do mundo e para orgulho do nosso povo. (...) mais perfeito estádio do mundo, dignificando a capacidade do seu povo e sua evolução em todos os ramos da atividade humana (A NOITE SPORTIVA, 16/6/1950, p.14).

No mesmo jornal, foram elencados números que demonstram a grandeza da edificação. Seis construtoras foram responsáveis pela obra que tinha: 25 mil cadeiras cativas, 3.319 cadeiras perpétuas, 422 alto-falantes, 2.100 camarotes, 831 tribunas de imprensa e rádio, 74 tribunas de honra, 32 mil lugares na geral, 120 mil na arquibancada, além do espaço para outras obras esportivas (A NOITE ESPORTIVA, 16/06/1950, p.14). Essa concepção de magnitude estabelece, como Novais e Sevcenko (1998) apontam, um excedente das proporções do corpo humano nas novas instalações e equipamentos modernos, como a Torre Eiffel, por exemplo. Ser vultoso era ser moderno.

Mario Filho foi reconhecido em todos os jornais investigados como um grande responsável pela obra, inclusive no convencimento da compra das cadeiras perpétuas ${ }^{9}$

\footnotetext{
${ }^{9}$ As pessoas que compraram as cadeiras teriam acesso vitalício ao estádio, como se fosse um terreno privado dentro do Maracanã, sendo inclusive declarado no imposto de renda como um bem, um imóvel e passado através de escrituras e heranças para dependentes. Na narrativa dos jornais, a organização das
} 
(cada uma custou cinco mil cruzeiros). Este trecho da coluna de Pedro Nunes com o título Soldado Conhecido no Jornal dos Sports exemplifica a narrativa sobre Mario Filho:

[...]falo do soldado Mario filho, que trabalhou tanto com suas crônicas incentivadoras, a objetiva de Angelo Gomes, as reportagens de seus redatores transformando JORNAL DOS SPORTS numa barricada, como o mais operoso dos obreiros do gigante que hoje se ergue majestoso no Maracanã, uma realização que impulsiona cem anos de progresso na vida esportiva de uma nação (JORNAL DOS SPORTS, 16/16/1950, p.4).

Destacamos o papel do periódico na esfera pública daquele período ao ser uma "barricada" (dando um sentido de guerra das narrativas) que defendeu a construção, um discurso que visava influenciar e capturar a ideia de consenso público sobre a importância do estádio.

A coluna do próprio Mario Filho no dia da inauguração reforça todas suas linhas de argumentação durante os anos que antecederam a concretização da obra, colocando-a como orgulho nacional:

Todo brasileiro devia sentir o mesmo orgulho de ser brasileiro. [...] O estádio inaugura uma nova época do esporte brasileiro. Hoje é um dia marcante. Um dia que é privilegio para a nossa geração. Outro motivo de orgulho para todos nós. E deve-se isso a um homem que acreditou em si mesmo. Que acreditou no Brasil (JORNAL DOS SPORTS, 16/06/1950, p.4).

Apoiar o estádio era associado a acreditar no Brasil e na sua capacidade de realizar grandes obras modernas. Outras colunas seguiram a mesma linha, destacando que a obra tinha sido feita com o coração, acionando o lado emotivo do leitor ${ }^{10}$. Propagandas e agradecimentos às empresas que participaram da obra, desde a que forneceu cimento até a que fez a pintura final, também foram destacadas nos jornais.

cadeiras perpétuas serviram para, ao lado da obra, sustentar o discurso da capacidade técnica e industrial do Brasil, que provaria o ingresso da nação na modernidade.

${ }^{10}$ Sugerimos que toda esta construção de significados sobre a competição e exacerbação de orgulho nacional refletiram na ideia de tristeza após a derrota para o Uruguai. A conquista do título surgia como legitimação simbólica de toda a narrativa edificada naquele contexto. No dia da estreia o jornal $O$ Globo destaca que "pessoas que jamais se ocuparam com o football, que jamais assistiram a um jogo, que jamais compreenderam o interesse dos outros pelo chamado esporte bretão - vibram com a batalha desta tarde e quase improvisam em técnicos, em entendidos, dando opiniões, emitindo sugestões (O GLOBO, 24/06/1950, p.1). Esta conjuntura nos indica a intenção de apontar um amplo envolvimento da população, além de mostrar que o agendamento na esfera pública do assunto Copa do Mundo criou um movimento de incitar opiniões sobre o tema, até de pessoas que supostamente não acompanhavam o esporte regularmente. Uma pesquisa divulgada na página 3, no mesmo dia, diz que: "apenas 2, de cerca de 20 que ouvimos - não se mostraram interessadas em comparecer aos Jogos da Copa do Mundo". 
Intercalada a essa narrativa sobre o estádio, encontramos a narrativa sobre a multidão que ocuparia o local. No dia 26 de junho de 1950, o jornal $O$ Globo repercute a estreia da seleção escolhendo o apoio do grande público como eixo principal da intriga: "Considerável massa humana acompanhou com vibração e simpatia constantes a primeira intervenção das cores nacionais no grandioso certame" (O GLOBO, 26/05/1950, p.1). O jornal destaca que o estádio recebeu 120 mil pessoas, "batendo todos os recordes continentais. Está assim, o Estádio Municipal cumprindo a sua missão de colaborar decisivamente para o desenvolvimento do esporte em nosso país" (O GLOBO, 26/05/1950, p.1). Na penúltima partida do Brasil na competição, com o público de mais de 160 mil pessoas, Mario Filho afirmou "o orgulho do torcedor é capaz de encher o maior estádio do mundo" (JORNAL DOS SPORTS, 13/07/1950, p.5).

Com toda essa gama de sentidos presente na linha discursiva dos jornais pesquisados, sugerimos que o estádio surge como o lugar preciso e real, que podemos situar e indicar no mapa da utopia nacional de atingir um lugar entre as grandes nações, além de fisicamente representar a grandeza do futebol na nossa cultura. A ideia de heterotopia de Foucault (2006) pode aqui ser utilizada nesta reflexão. Ao mesmo tempo em que ele simboliza o espaço da realização da utopia nacional, quando não se tem uma partida, ele perde a vivacidade, se torna sem vida. Ele é o local em que se reúne periodicamente para viver emoções e sensações, ritos festivos simbólicos, onde se tem um envolvimento com o jogo. Este trecho do jornal $O$ Globo repercutindo a estreia do Brasil, simboliza esta construção de significados: "o coração da cidade e mesmo do Brasil se deslocara para o Derby e ali, numa das maiores concentrações humanas jamais vistas no país começara a vibrar pela vitória de nossas cores" (O GLOBO, 26/06/1950, p.10). A reportagem ainda reforça que a "palpitações dessa monstruosa fonte de vida" irradiaram por toda cidade e para o país por conta da transmissão radiofônica, indicando a ideia do estádio como "centro" que distribui sentidos para a "periferia".

Além disso, é interessante destacar que no estádio existe um recorte singular do tempo, vive-se outra temporalidade durante uma partida, diferente do dia a dia “normal”. Ali temos uma atenção focada nos valores simbólicos do jogo, a intensidade proposta por Gumbrecht (2007), vivendo momentos inesquecíveis, oscilando entre felizes e dolorosos, que não voltariam mais. $\mathrm{O}$ mito da alma do futebol nacional havia encontrado o seu local e sua casa, um corpo para encarnar, um corpo de tamanho colossal que tinha em sua presença física e emocional seu grande significado para uma 
narrativa de país. Este corpo, recheado de lugares profundos, e ao mesmo tempo locais apenas durantes os jogos, simbolizava a utopia do gigante, segundo Foucault (2006). Ele se torna o local de aspirações dos amantes dos esportes: ver um jogo no estádio, comemorar um título, do jogador querer atuar ali para ser reconhecido, da criança que sonha em um dia jogar neste "templo". Estes valores imaginários agregados ao estádio estão articulados ao prestígio da heterotopia. Para Foucault (2006), esses espaços no mundo moderno são heterogênios, marcados por processos recheados de relações que se misturam, que dialogam, se contradizem e que, ao mesmo tempo, proporcionam sentidos ao local. Em suma, acreditamos que o estádio municipal se torna um local que fala, uma "mídia" que servirá de mediadora de narrativas e terá nas reapropriações de sentidos realizadas pelos frequentadores (torcida) uma atuação decisiva na esfera pública na qual o jogo de narrativas sobre o esporte será frequentemente disputado. $\mathrm{O}$ que antes acontecia em outros estádios, torna-se amplificado por conta de toda a narrativa que apresentamos que consolidou o Maracanã "o" espaço legitimado para tais embates.

\section{Interações e apropriações no torcer e ocupar o Maracanã}

Disputar o local de fala no estádio é um processo de múltiplos embates e repleto de reapropriações. A própria ideia de "batizar" o estádio municipal, logo após a final da Copa, com o nome do prefeito general Ângelo Mendes de Morais, simbolizou um mero ato burocrático. Por mais que encontrássemos nas narrativas uma busca pelo consenso e a necessidade desta homenagem (inclusive com apoio de Mario Filho), o torcedor preferiu chamar o estádio de Maracanã, por conta da proximidade do rio onde fora construído, que dava nome ao bairro ${ }^{11}$. As proposições apresentadas pelos jornais com as alcunhas "colosso do Derby", "Estádio Municipal" foram desaparecendo das reportagens, consolidando o nome Maracanã. Mesmo com a derrota na final da Copa do Mundo e o sentimento de tristeza coletivo compartilhado pelos mais de 200 mil espectadores da "maior tragédia nacional", segundo Da Matta (1982), o estádio se alicerçou como o centro do nosso futebol.

Novamente resgatamos a ideia de que este centro funciona como o local que irradia comportamentos e maneiras de torcer, além de mitos do futebol. O Maracanã e suas disputas de narrativas dariam o norte ao futebol nacional. É preciso jogar ali para

\footnotetext{
${ }^{11}$ Em 1966, o nome oficial do estádio foi alterado com a morte de Mario Filho, em uma homenagem ao jornalista que, como vimos, foi um dos maiores incentivadores de sua construção.
} 
chegar ao olimpo dos atletas, por exemplo. Ele se torna o espaço central da celebração de uma identidade nacional. Neste sentido, Novais e Sevcenko (1998) resgatam a ideia de Freyre ao designar o Rio de Janeiro como aglutinador da modernidade, criando uma aura mítica da cidade e, no nosso caso, do Maracanã. Para Novais e Sevcenko estar na capital federal é decisivo:

O Rio passa a ditar não só as novas modas e comportamentos, mas acima de tudo os sistemas de valores, o modo de vida, a sensibilidade, o estado de espírito e as disposições pulsionais que articulam a modernidade como experiência existencial e intima (NOVAIS e SEVCENKO, 1998, p. 522).

Neste sentido, tomamos alguns conceitos de esfera pública de Habermas para indicar o estádio como este espaço de interação entre campos que pretendem colocar suas narrativas como hegemônicas. Sugerimos os torcedores como pessoas privadas que se reúnem em público e reivindicam as autoridades (dirigentes, treinadores e jogadores), criticando-as para induzi-las a reproduzir hábitos que determinado grupo julga como correto. Seria o ter raça, ter um jogador de qualidade, escolher determinado estilo de jogo, por exemplo. O cantar, xingar, vaiar, vibrar interferem diretamente na interação do time e do jogo. Acreditamos que na troca simbólica de significados neste ambiente comunicacional, a atuação de um elemento sugere uma reação dos demais, seguindo o modelo orquestral de comunicação de Winkin (1998) e não telegráfico que colocaria o torcedor como alguém passivo. Sodré (1977) indica este lado participativo dos espectadores sugerindo que a manifestação dos torcedores interfere no jogo. Assim, a torcida se torna um agente fundamental neste espaço público.

Se os cafés se tornam palcos da disputa de narrativas e representações para legitimar discursos no conceito de esfera pública burguesa de Habermas (1984), levantamos a noção de que a sociabilidade presente nos estádio atua nesta linha. Os torcedores seriam os debatedores que procuram exercer seu papel de estimular opiniões. Cantar, vaiar deve ser acompanhado pelos demais, ganhando uma força que estimularia a concepção de que aquela argumentação é hegemônica. Como Habermas (1984, p.47) define: "a medida que a "cidade" assume suas funções culturais, modifica-se não só o sustentáculo da esfera pública, mas ela mesma se modifica". O estádio se torna uma esfera pública e todas as intervenções da torcida são uma forma de atuação política performativa. Com todo o simbolismo que o Maracanã obteve na sociedade, e sua concepção moldada como local democrático, a cidade ganha uma nova esfera pública, 
uma nova arena de disputa no espaço público moderno ${ }^{12}$, um local de posicionamento político e social no período de redemocratização do país.

Assim, a torcida que se organiza obteria maior sucesso na legitimação de suas ideias, comportamentos e costumes neste novo ambiente de discussão. A construção de tradições ergue-se no nível micro, através das contendas entre os torcedores, dando suporte a imaginários que serão utilizados no nível macro na formulação de grandes mapas culturais sobre o futebol. Estabelece-se na voz da torcida a opinião pública sobre o futebol, como a única "fonte de leis", influenciando na demissão de treinadores e críticas a jogadores, por exemplo.

Deste modo, controlar estas vozes e "discipliná-las" se torna um ponto-chave na disputa de narrativas. Vejamos alguns exemplos durante a Copa do Mundo de 1950 sobre o torcer e ocupar o Maracanã. O jornal Diário da Noite traz uma reportagem no dia da inauguração do "gigante do Maracanã", alcunha escolhida pelo periódico, que "ensina a entrar no estádio", com calma, de modo "civilizado" e ordeiro, atentando para qual será o local do leitor. Os espaços destinados às camadas mais populares, por exemplo, tem o acesso simples, como afirma este trecho: "O acesso às arquibancadas e à geral é de assimilação clara. Não há motivos para confusões, enganos" (DIARIO DA NOITE, 16/06/1950, p.6). Já na véspera da partida final contra o Uruguai, o Jornal dos Sports "apresenta a maneira mais fácil de ingressar no Estádio Municipal do Maracanã. Já agora, a maioria conhece a facilidade de acesso para todas as localidades, mas, nunca é demais conhecer-se o portão mais próximo, principalmente para os portadores das cadeiras cativas e numeradas, nos seus múltiplos setores" (JORNAL DOS SPORTS, 15/07/1950, p.5). A reportagem se encerra com o pedido para que as massas ganhem suas localidades sem atropelos e congestionamentos.

A forma pedagógica e mandatária do jornal vêm acompanhadas de desenhos e fotos sobre o estádio e suas entradas. Encontramos nas narrativas de ordenar a ocupação do Maracanã uma tentativa de hierarquização social. Essa hierarquia busca reproduzir arranjos e configurações já presentes na sociedade. As cadeiras numeradas, perpétuas e a tribuna de honra, por exemplo, concederiam um status e reconhecimento nas relações de poder presentes na sociedade que tentam ser reproduzidas neste novo espaço público.

\footnotetext{
${ }^{12}$ Morel (2006) destaca as praças, teatros, mercados e largos como mídias e arenas de disputas simbólicas na construção do espaço público moderno carioca no período pós-Independência do país. Este locais, ocupados por vozes que pretendiam emitir opiniões e influenciar decisões do monarca, tinham suas tradições políticas e regras de convivência singulares na disputa simbólica. Para nós o Maracanã surge como um espaço similar no contexto pós-guerra.
} 
Como neste trecho do jornal $O$ Globo após a inauguração do estádio que frisa a presença de autoridades e embaixadores no local, como forma de legitimar a importância do evento e o espaço que eles ocupavam como distinto: "Como não poderia deixar de acontecer, a rodada inaugural da Copa constituiu marcante acontecimento social-esportivo. Prestigiando a Inauguração, ocupava a Tribuna de Honra o presidente da república, general Eurico Gaspar Dutra” (O GLOBO, 26/06/1950, p.10).

Seguindo a ideia das contradições, sobreposições e posições presentes na heterotopia, ao mesmo tempo em que o espaço é publico é também privado. Por mais que existam tentativas de se reproduzir posições sociais no estádio, a lógica é negociada através dos recursos simbólicos presentes dentro deste novo local de disputa de narrativas. Temos as performances durante um evento que não deixam de ser uma maneira de tencionar posições, invadir espaços, flexibilizando tais posições. Cada um tem seu lugar, da cadeira perpétua, algo individual e planejado como local de distinção social, passando pelos locais das torcidas organizadas, por exemplo, espaço do associativismo, demarcado por embates e ocupações ao longo do tempo. Estes novos locais apropriados pelas torcidas modificam modos de se torcer e de assistir ao jogo, criando novas experiências, locais perigosos e locais tranquilos, que serão assim representados pelas narrativas jornalísticas.

Vão surgir, por exemplo, locais perigosos e advertidos pela imprensa, por estarem nas fronteiras entre torcidas diferentes, em especial as organizadas. As contendas passam a ser "resolvidas" entre as torcidas, fazendo a intervenção do poder público, através da polícia, ser rejeitada e caracterizada como "inimiga" por quaisquer lados das torcidas organizadas. Nas narrativas jornalísticas essas contendas das organizadas passam a ser construídas como algo ruim e perigoso.

Toledo (2000) destaca que os jornais dos anos 1940, já buscavam uma forma de adestrar o comportamento dos torcedores, que com o forte estímulo emocional, acabavam resultando em brigas, fazendo com que a presença policial fosse imposta pela narrativa jornalística como "elemento indissociável das jornadas esportivas" (TOLEDO, 2000, p.61). A vigilância constante da polícia nestes locais para manter a ordem é bem similar ao que Chalhoub (2001) destaca nos botequins cariocas.

Seguindo a proposição de Chalhoub, indicamos outros pontos importantes presentes nos botequins que também se estabelecem no estádio: a) um local de refúgio do dia a dia alucinante da modernidade; b) um local de resistência de determinados grupos para viver outras culturas, como se fossem guetos; e c) uma nova sociabilidade 
ao erguer-se uma solidariedade entre os pertencentes à mesma "nação", onde se permite extravazar sentimentos supostamente contidos no processo civilizador. Hábitos rejeitados em outras esferas se tornam comum, como, por exemplo, o "homem chorar", ao mesmo tempo em que dialoga como espaço de manifestação de virilidade, como Hornby e Schwartz (2013) apontam. Também sinalizamos a organização de torcidas como "comunidades imaginadas" (ANDERSON, 2008) nos espaços públicos, algumas até remetendo-se ao nome de nações, criando maneiras de emancipar-se e até agir na sociedade $^{13}$.

A autonomia e criatividade na sociabilidade dos grupos, que rejeitam a forma de ordenação estabelecida pelo poder público, pode nos indicar uma resistência da cultura popular que reapropriou o torcer, contra um modo burguês de ver o jogo, como em outros esportes, como o tênis, por exemplo, onde o árbitro pede à torcida para que faça silêncio e é prontamente atendido. Nestas novas formas de torcer, o papel dos meios de comunicação é essencial ao maximizar ou minimizar os acontecimentos de acordo com o momento. Em certas situações o respeito aos rituais construídos do estádio, como bandeiras e faixas, são exibidos como grande festa, ao mesmo tempo em que dependendo da angulação, os novos hábitos surgem como nocivos ao esporte e sua prática civilizatória, como se exaltar e ver o jogo de pé. O ver e torcer de uma "forma burguesa" condenaria as manifestações populares neste local.

Obviamente os casos entendidos como de violência são os mais enfatizados como prejudiciais. Mas também encontramos receio das narrativas com a ordem econômica. Nas edições que precederam a partida final contra o Uruguai, o Jornal dos Sports destaca a preocupação com os cambistas na venda de ingressos, que no jogo anterior contra a Espanha atuaram livremente, e com a entrada em massa de torcedores (também no jogo contra a Espanha), que, sem ingresso, derrubaram uma das catracas e invadiram o estádio. Para solucionar este ponto a reportagem enfatiza: "policiamento a cargo da polícia do exército", e conclui “isso quer dizer que não haverá atropelos, nem brigas, que tudo ocorrerá normalmente, sem as cenas lamentáveis verificadas por ocasião da última partida, contra a Espanha. [...] ninguém entrará se não tiver ingresso" (JORNAL DO SPORTS, 15/07/1950, p.3). Na página três, o mesmo periódico destaca a

\footnotetext{
13 Santos (2004), ao entrevistar presidentes de torcidas organizadas, como a Gaviões da Fiel (Corinthians), por exemplo, mostra como essas associações buscam ultrapassar a esfera esportiva e atuar como entidade política com a exibição de faixas pela torcida durante a ditadura que pedia "anistia ampla, geral e irrestrita". A ideia de se organizar e "fiscalizar" os dirigentes dos clubes também é um argumento apresentado pelos torcedores.
} 
alta procura de ingressos para a final da Copa, que fez pessoas dormirem nas filas e a organização estabelecer o limite de compra de dez ingressos por pessoa.

Acreditamos que essas condutas que serão definidas como corretas, violentas ou apaixonadas são influenciadas pelas representações nos jornais. Após a derrota para o Uruguai, por exemplo, as notícias seguiram a linha de elogiar o comportamento dos torcedores brasileiros, posto como positivo, mesmo depois da derrota, citando também que alguns não aguentaram de emoção e "desmaiaram diante do placar inesperado" (DIARIO DA NOITE, 17/07/1950, p.1), reforçando nossa argumentação de local de emoções e hiperestímulos. Como Losnak (2011) salienta, analisar essa produção jornalística é uma contribuição importante ao observar seu papel de agente social que visa delinear a compreensão que a sociedade elabora sobre si mesma. A ideia de "aceitar civilizadamente" a derrota se encaixa na narrativa de país moderno, que jamais teria a atitude "selvagem" de "hostilizar os vencedores". Já a de desmaiar com a "emoção da derrota", indica o lado afetivo e simbólico que o futebol representava para a sociedade.

Todavia, como já indicamos, essas narrativas não são absorvidas de modo passivo pela torcida. Esta esfera pública está permeada por interações que vão insinuar e indicar reapropriações deste "processo civilizador". A seguir vamos apontar algumas dessas pistas encontradas no corpus. A primeira é a ocupação dos locais e suas formas de sociabilidade. Como Fuchs (2015, p.20) ressalta, a esfera pública é, simultaneamente, processo e espaço. Neste processo a torcida se articula com o objetivo de ocupar espaço, obtendo uma fatia maior do local, podendo através da vantagem numérica direcionar os cantos e assim, influenciar a noção de opinião pública neste ambiente. Logo, começam a ser formadas comunidades e grupos que vão estabelecer identidades e confrontar adversários. Aqueles que não convergissem em determinadas opiniões seriam "o outro", erguendo formas de sociabilidade nesta esfera pública. Não é difícil encontrar relatos de parcerias de diretores de clubes e torcidas que procuram ditar opiniões que, em grande medida, visam proteger mais direitos individuais de mandar no clube do que concentrar-se no que seria "o bem comum" da agremiação. Seria uma associação com o objetivo de controlar “a voz" hegemônica neste espaço público e gerenciar seus símbolos, assumindo interesses específicos de determinados grupos. Como o espaço do estádio não é totalmente público, já que se paga para entrar, é 
comum termos ingressos gratuitos a torcedores das chamadas "organizadas" que atuam, em muitos momentos, na defesa do grupo que os patrocinou ${ }^{14}$.

Aqui, apontamos que o estádio também se torna um exemplo da complexidade dos processos sociais e da esfera pública. Por mais que o "todos tem voz" seja exaltado dentro deste local, o caráter particularista e desigual das organizadas, confrontam o alcance da liberdade de expressão de cada torcedor. Não são todos que detém dos recursos de confrontar o poder sonoro das torcidas organizadas, indicando um limite no confronto desta esfera pública (Habermas, 1984). Na associação de grupos dentro do local temos o que Habermas indica como aproveitamento do "oligopólio da formação publicisticamente efetiva e politicamente relevante de reuniões e associações" (HABERMAS, 1984). O torcer através da "organizada" pode ser entendido como uma tentativa de impor e invadir, tendo como posição privilegiada de superioridade, o espaço de forma deliberada e, em algumas situações, de forma agressiva. Em resumo, um torcedor sozinho pode gritar o quanto quiser, mas deve estar inserido e "iniciado" na sociabilidade e interações presentes no estádio, simbolizado pelas organizadas. É no controle deste grupo que amplifica-se o discurso e até certo ponto o legitima.

Toledo (1996) afirma que as primeiras torcidas uniformizadas surgiram no Brasil no fim dos anos 1930 e início dos anos 1940. Antes disso, os clubes tinham os chamados torcedores símbolos, que representavam o time, com prestígio na imprensa e exerciam influência sobre significativa parcela de outros torcedores. Santos (2004) destaca que o primeiro a equipar os torcedores com uniformes e música foi Jaime Rodrigues de Carvalho, flamenguista, criando a charanga rubro-negra. A charanga mantinha uma banda de música para incentivar o time e animar os torcedores durante as partidas. Santos afirma que aos poucos os torcedores símbolos foram perdendo espaço para as torcidas organizadas, com uma organização diferente, mais burocratizada, que se consolidou no início dos anos 1970. Julgamos essa reapropriação do torcer, que se desloca do indivíduo para um associativismo, uma evidente recondução de sociabilidade no espaço público dos estádios de futebol.

Logicamente esta associação não é o único fator determinante para fortalecer determinadas opiniões. Um torcedor pode ser seguido pelos demais aleatoriamente e o canto ganhar todo o estádio, como neste exemplo durante a partida Brasil e Espanha, no quadrangular final da Copa do Mundo de 1950.

\footnotetext{
${ }^{14}$ Essa atuação, em alguns casos, extrapolam o viés esportivo, com diretores, presidentes de clubes e de torcidas pleiteando e alcançando cargos públicos em eleições.
} 
O Brasil venceu por 6 a 1 e as narrativas apontam a importância da torcida em apoiar, lotar o estádio e aplaudir a seleção. O jornal $O$ Globo no dia seguinte a vitória destaca uma situação que nos ajuda a compreender as relações existentes na torcida que extrapolam o ordenamento pretendido pelos organizadores, indicando a incorporação de outros elementos, neste caso, uma canção de uma manifestação cultural também relevante na formação da identidade nacional: o samba.

A maior praça de esportes do mundo foi ficando pequena para o enorme interesse que a peleja despertava, discutida a sua lotação pela surpresa da falta de ingressos. [...] Multidão que cantava alegremente com entusiasmo o triunfo estrondoso. Enquanto os lenços - dezenas de milhares de lenços brancos - davam o clássico adeus ao perdedor, enchia o ar uma canção famosa do carnaval carioca de alguns anos. A despedida musicada em primeira audição, com a letra alusiva aos adversários que perdiam por tantos gols. E a "touradas de Madri" teve o seu colorido futebolístico, aplicando a letra "AL cuento": Eu fui às touradas em Madri/E conheci uma espanhola/ natural da Catalunha/queria que eu tocasse castanholas/e pegasse um touro a unha/ caramba, caracoles/sou do samba, não me amoles/ pro Brasil vou partir/ isso é conversa mole/ para boi dormir (O GLOBO, 14/07/1950, p.12).

Os jornais pesquisados afirmam que as canções serviram para conduzir os jogadores ao que foi definido como "um belo espetáculo". Mario Filho já cobrava esta posição do torcedor de não só ver, mas participar do jogo e confiar na seleção, que foi seguida pelos torcedores, como mostra este trecho do $O$ Globo:

Os aficcionados perceberam que o quadro está precisando ganhar confiança em seus próprios recursos, adquirir consciência da própria força. E por isso procurou incentivar os representantes do football brasileiro em todos os momentos, principalmente nas fases de indecisão (O GLOBO, 26/06/1950, p.10).

Com a vitória por um placar inesperado sobre a Espanha e o orgulho de estar presenciando aquela partida, Mario Filho vai além, definindo o canto das "touradas de Madri” como a conexão entre público e jogadores: "aquele era o limite, o último marco da emoção humana num campo de futebol" (JORNAL DOS SPORTS, 13/07/1950, p.5). Para nós, esta argumentação se aproxima da ideia de intensidade que apresentamos anteriormente. Também sugerimos a noção de que a torcida funciona como extensão do corpo do time.

No intervalo entre a euforia da vitória contra a Espanha e a partida final contra o Uruguai, esta reportagem no Jornal dos Sports indica que por mais que se tente impor determinados comportamentos, o ritual do torcer pode ou não assimilá-los. A matéria 
diz que o "Grito de Guerra da Torcida do Brasil" composto por Lamartine Babo ${ }^{15}$, apresentado como um dos maiores artista da música popular brasileira, seria divulgado pelos alto-falantes do estádio na final contra o Uruguai. A intriga ressalta que o campeonato Mundial "sacudiu os nervos do Brasil em peso", e o compositor ofereceu o hino a Jaime de Carvalho, chefe da chamada torcida organizada do Brasil, como uma homenagem à torcida:

Eu sou brasileiro/Tu é brasileiro/ Muita gente boa brasileira é! Vamos torcer com fé/ No nosso coração/ Vamos torcer para o Brasil ser campeão! Um...dois...três...quatro...cinco...seis...sete...oito...nove...Bis Pra doze faltam três Brasil! Salve! Salve! O nosso estádio Municipal/ No campeonato Mundial/Verde...ouro...anil.../BRASIL! BRASIL! BRASIL! (JORNAL DOS SPORTS, 16/07/1950, p.6).

Não encontramos em nenhum dos jornais pesquisados menções que esta canção foi reproduzida no estádio. Seja pela situação tensa da final, onde o placar apertado não suscitou um clima festivo, seja pela "torcida organizada" da seleção não ter traços similares aos que conhecemos hoje, este processo de reprodução de uma canção neste espaço não é mecânico. Supomos que no contexto do associativismo das torcidas organizadas atual a "chance da canção pegar" poderia ser maior.

Mesmo ressaltando que as torcidas organizadas se consolidam nos anos 1970, encontramos algumas pistas nos periódicos pesquisados do caminho que tais modificações poderiam percorrer. $\mathrm{O}$ afeto estimulado no estádio pela seleção foi dando lugar às emoções focalizadas nos clubes. Uma semana após o fim da Copa do Mundo, ao falar sobre o amistoso entre Bangu e Flamengo, Mario Filho em sua coluna no Jornal dos Sports, aproveitou para reforçar a relevância da praça de esportes para o futebol nacional e destacar o lado afetivo na narrativa que iria moldar o significado de "maior do mundo":

Um simples match amistoso serviu para dar uma grande demonstração do amor do povo pelo football. [...] A multidão que foi ao Estádio não caberia em São Januário, o que dá uma ideia do que vai ser este ano de cinquenta para o football carioca. [...] Confundiu-se dor de derrota com desilusão de football. Com descrença em futebol. Como o público poderia descrer do melhor football do mundo? Do footbal que merecera o monumento do maior estádio do mundo? [...] O Estádio foi construído para que o povo pudesse ver o seu football. Porque os campos não chegavam mais. $\mathrm{O}$ campeonato do mundo demonstrou que os cálculos dos que idealizaram o Estádio não foram exagerados.

\footnotetext{
15 O autor compôs algumas marchinhas de carnaval famosas como "o teu cabelo não nega". Em 1949 também compôs os hinos ditos como "não-oficiais" dos onze clubes cariocas que disputaram o campeonato da cidade naquele ano. Até hoje, os hinos compostos por Babo são os mais populares e os mais cantados nos estádios, sobrepondo a importância dos hinos oficiais.
} 
[...] O público está defendendo o que ama: o seu football e o seu Estádio. E nada mais natural do que seja assim. Foi o amor do povo pelo football que fez do football brasileiro o melhor do mundo e que tornou uma necessidade a construção do maior estádio do mundo. $\mathrm{O}$ povo tem razão para orgulhar-se do seu football que é o melhor do mundo e do seu estádio que é o maior do Mundo (JORNAL DOS SPORTS, 25/07/1950, p.5-8).

O jornal A Noite também traz uma narrativa similar: "O campeonato do mundo se foi, a Copa Jules Rimet também, mas o colosso do Maracanã ficou para a admiração e o respeito do povo brasileiro" (A NOITE, 24/07/1950, p.1). O jornal O Globo destaca a alta demanda por estar no estádio: "o público, impaciente pela demora sem ser atendido na compra de ingressos, acabou invadindo o Estádio para assistir ao amistoso Flamengo x Bangu" (O GLOBO, 25/07/1950, p.11). Com o final da Copa do Mundo, aquele espaço de apoio à seleção é reconfigurado, já que outros clubes fariam suas apresentações ali. A ocupação deste novo local passa a se dar por grupos opostos. O jornal Diário da Noite enfatiza esta situação:

Uma semana após o dramático desfecho da Copa do Mundo, a torcida carioca voltou, ontem, ao Maracanã, desta vez dividida em grupos, um pró-Flamengo e outra pró-Bangu. A renda da partida - cerca de 300 mil cruzeiros, com ingressos a preços populares e muitos "caronas" foi o primeiro atestado de que, para o torcedor carioca, football não morreu. (DIARIO DA NOITE, 24/07/1950, p.12).

Além do futebol não ter morrido, novos ritos de apossar-se de locais do Maracanã começam a ser elaborados. Esta mídia Maracanã agora tem claramente lados opostos, disputando através de rituais de provocação, símbolos, cantos e bandeiras, dinâmicas populares de criação de novas culturas neste espaço de lazer, diferentes dos ideais civilizatórios burgueses de torcer vistos no período de sua inauguração. Provocam-se, assim, tensões sociais recorrentes neste processo, com novas regras e quebras de convenções com o objetivo de institucionalizar um "ritual" próprio neste espaço tão simbólico para o esporte nacional.

\section{Considerações finais}

O espaço público é construído através de um intenso jogo de apropriações que envolvem a batalha de narrativas, ocupações de locais e disputas simbólicas. Neste sentido, defendemos a ideia que o Maracanã funciona como uma mídia. Nele novas formas de interação e sociabilidade se constroem, se comunicam e se amplificam. A intensidade que o futebol incitava na sociedade brasileira, o desejo de ingressar na 
modernidade desenvolvimentista europeia, associada ao fato de sediar a Copa do Mundo criaram um ambiente fértil para a narrativa do Maracanã. Este novo espaço urbano conseguiu agregar uma série de significados tanto sobre o esporte como para embates públicos de outros campos. Sua magnitude simbólica e física irradiou sentidos pelo território nacional e para diferentes classes sociais. Estar no Maracanã era pertencer a um "novo Brasil" e vivenciar os estímulos eletrizantes da "vida moderna" neste espaço de sociabilidade de multidões. O Maracanã, com toda a narrativa afetuosa, como vimos em Mario Filho, se apresenta como local de emoções incontroláveis da Modernidade.

Entretanto, essa narrativa escolhe determinados assuntos e descarta outros, moldando representações que visavam construir hábitos sobre o torcer. Pouco mais de um mês após ser inaugurado, as contendas entre torcidas passaram a edificar novos comportamentos que não eram os propostos pela narrativa jornalística. Sugerimos que a grandeza deste espaço urbano e toda sua simbologia o tornou, por exemplo, um palco para protestos e vaias até no chamado "um minuto de silêncio". O disciplinar e civilizar não "colaram" neste ambiente, por mais que o conceito de "novas arenas" procurem retirar a espontaneidade de alguns comportamentos e direcionar os hábitos exclusivamente para o consumo.

Esta constante interação implica na negociação do Maracanã como cenário social importante, no qual regras sociais vão emoldurar uma espécie de vitrine social (através dos atuais camarotes) ao mesmo tempo em que se torna espaço de confronto e de produção simbólica dos torcedores classificados como “populares”. Neste espaço os impactos dos meios de comunicação em definir costumes sofrem constantes reapropriações. A narrativa sobre o Maracanã está longe de ser algo único, vertical e algo imposto. Ela é construída absorvendo, mesmo quando critica, culturas populares dos torcedores que ali travam embates. Seu simbolismo consegue ir além da ideia de uma "simples" construção de cimento. O local físico fantasiado e ideal para a nação viver sua almejada grandiosidade projeta significados no imaginário nacional sobre o "maior do mundo" baseados no afeto, intensidade, consumo e emoções, numa construção contínua que perdura até os dias atuais e reforça o simbolismo do futebol em nossa sociedade.

Todavia, o espaço Maracanã como palco de disputa de narrativas enfrenta hoje um reflexo da apropriação do capital frente a bens simbolicamente públicos como o 
estádio. Após a Copa do Mundo de 2014 e a reforma bilionária, o controle deste local foi entregue ao Consórcio Maracanã. O que seria uma praça de esportes que durante seus mais de sessenta anos abrigava uma média de três jogos por semana, hoje se encontra fechado, a espera de um jogo "lucrativo" para ser aberto, perdendo a sua dimensão simbólica em ser este palco de disputas tão relevante ao esporte e à sociedade brasileira. O "gigante de concreto" sem jogos perde sua vivacidade, seu caráter de expor narrativas, diminuindo um símbolo nacional.

\section{Referências}

FUNDAÇÃO BIBILOTECA NACIONAL. A Noite, Rio de Janeiro, disponível em http://memoria.bn.br/hdb/periodico.aspx. Acesso em 18/09/2017.

ANDERSON, Benedict; BOTTMAN, Denise. Comunidades imaginadas: reflexões sobre a origem e a difusão do nacionalismo. Editora Companhia das Letras, 2008.

BARBOSA, MARIALVA CARLOS. Cenários de transformação: Jornalismo e História no século XX. Revista FAMECOS: mídia, cultura e tecnologia, v. 19, n. 2, 2012.

CHALHOUB, Sidney. Trabalho, lar e botequim: o cotidiano dos trabalhadores no Rio de Janeiro. SP: Unicamp, 2001.

DA MATTA. Carnavais, malandros e heróis. Rio de Janeiro: Zahar, 1978.

Universo do futebol: esporte e sociedade brasileira. Rio de Janeiro: Pinakotheke, 1982.

Diário da Noite, Rio de Janeiro, disponível em http://memoria.bn.br/hdb/periodico.aspx Acesso em 11/09/2017.

ELIAS, Norbert. O processo civilizador 2. Vol. 2. Zahar, 1993.

FOUCAULT, M. Outros espaços. In: BARROS DA MOTTA, M. (Org.). Estética: literatura e pintura, música e cinema. Rio de Janeiro: Forense Universitária, 2006. p 411-422.

FRANCISCATO, Carlos Eduardo. A fabricação do presente: como o jornalismo reformulou a experiência do tempo nas sociedades ocidentais. Universidade Federal de Sergipe, 2005.

FRANCO, Hilário Jr. A Dança dos Deuses: futebol, cultura e sociedade. São Paulo: Companhia das Letras, 2007.

FREYRE, Gilberto. Foot-ball mulato. Diário de Pernambuco, Recife, 17 jun. 1938, p.4.

2003. Casa Grande \& Senzala. Formação da família brasileira sob o regime patriarcal. Recife: Global Editora.

FUCHS, Christian. Mídias Sociais e a Esfera Pública. Revista Contracampo, v.34, n.3. p.05-80, 2015.

GUMBRECTH, Hans Ulrich. Elogio da Beleza Atlética. Trad. Fernanda Ravagnani. São Paulo: Companhia das Letras, 2007. 
. Atmosfera, ambiência, Stimmung: sobre um potencial oculto da literatura. Contraponto, 2014.

HABERMAS, Jürgen. Mudança estrutural da esfera pública: investigações quanto a uma categoria da sociedade burguês. RJ: Tempo Brasileiro, 1984.

HOBSBAWM, Eric. A era dos impérios: 1875-1914. Editora Paz e Terra, 2015.

HOBSBAWN, E.; RANGER, T. Invenção das Tradições. Rio de Janeiro: Nova Fronteira, 2012.

HORNBY, Nick, Christian SCHWARTZ. Febre de bola. Editora Companhia das Letras, 2013.

Jornal dos Sports, Rio de Janeiro, disponível em http://memoria.bn.br/hdb/periodico.aspx Acesso em 15/09/2017.

LOSNAK, C. J. Jornais e Ferrovia: uma intervenção social. SP: Anais Confibercom, 2011.

LOPES, José Sérgio Leite. A vitória do futebol que incorporou a pelada - A invenção do jornalismo esportivo e a entrada dos negros no futebol brasileiro. Revista usp 22 (1994): 64-83.

MASCARENHAS, Gilmar. Entradas e bandeiras - a conquista do Brasil pelo futebol. Rio de Janeiro: EdUERJ, 2014.

MOREL, Marco. As transformações dos espaços públicos: imprensa, atores políticos e sociabilidades na Cidade Imperial (1820-1840). RJ: Hucitec, 2006.

MOTTA, Luiz Gonzaga. Análise pragmática da narrativa jornalística. In: LAGO, Claudia; BENETTI, Márcia. Metodologia de pesquisa em Jornalismo. Petrópolis: Vozes, 2007.

2013.

Análise Crítica da Narrativa. Brasília: Editora Universidade de Brasília,

NOVAIS, Fernando A; SEVCENKO, Nicolau. História da Vida Privada no Brasil. vol. 3. SP: Companhia das Letras, 1998.

O Globo, Rio de Janeiro, disponível em http://acervo.oglobo.globo.com/consulta-aoacervo/ Acesso em 13/09/2017.

RICOEUR, Paul. Tempo e Narrativa. Vol. 1. São Paulo: Martins Fontes, 2010.

SANTOS, Tarcyanie Cajueiro. Dos espetáculos de massa às torcidas organizadas: paixão, rito e magia no futebol. São Paulo: Annablume, 2004.

SARMENTO, C. E. B. A construção da nação canarinho: uma história institucional da seleção brasileira de futebol, 1914-1970. Rio de Janeiro: Editora FGV, 2013.

SEVCENKO, N. Futebol, metrópoles e desatinos. In: Revista da USP, Dossiê Futebol, (22): 30-37, 1994.

SINGER, Ben. Modernidade, hiperestímulo e o início do sensacionalismo popular. $\mathbf{O}$ cinema e a invenção da vida moderna. São Paulo: Cosac \& Naify, p. 95-123, 2004.

SODRÉ, Muniz. O monopólio da fala: função e linguagem da televisão no Brasil. Vol. 16. Editora Vozes, 1977. 
TOLEDO, Luís Henrique. Torcidas Organizadas. Dissertação de Mestrado em Antropologia Social, Faculdade de Filosofia, Letras e Ciências Humanas da Universidade de São Paulo, 1996.

WINKIN, Yves. A Nova Comunicação: Da teoria ao trabalho de campo. Campinas: Papirus, 1998. 


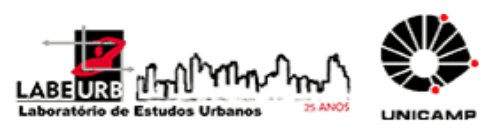

\section{Para citar essa obra:}

BRINATI, Francisco Angelo e MOSTARO, Felipe. Maracanã como mídia urbana: as narrativas jornalísticas, apropriações e interações no torcer no "maror do mundo" In: RUA [online]. no 24. Volume 1 - p. 211-236 - e-ISSN 2179-9911 - junho/2018. Consultada no Portal Labeurb Revista do Laboratório de Estudos Urbanos do Núcleo de Desenvolvimento da Criatividade. http://www.labeurb.unicamp.br/rua/

Capa: Acervo Herculno Gomes/SUDERJ/VEJA. Disponível em: https://veja.abril.com.br/esporte/maracana-abre-as-portas-ainda-em-obras-como-em-1950/

Laboratório de Estudos Urbanos - LABEURB

Núcleo de Desenvolvimento da Criatividade - NUDECRI

Universidade Estadual de Campinas - UNICAMP

http://www.labeurb.unicamp.br/

Endereço:

\section{LABEURB - LABORATÓRIO DE ESTUDOS URBANOS}

UNICAMP/COCEN / NUDECRI

CAIXA POSTAL 6166

Campinas/SP - Brasil

CEP 13083-892

Fone/ Fax: (19) 3521-7900

Contato: http://www.labeurb.unicamp.br/contato 